\title{
Pengaruh Partisipasi Penyusunan Anggaran, Kejelasan Sasaran Anggaran Dan Struktur Desentraliasasi Kinerja Manajerial SKPD Lombok Barat
}

\author{
Ahmad Juaini ${ }^{1}$ \\ Fakultas Ekonomi dan Bisnis \\ Universitas Mataram, Indonesia. \\ Email: juaini_lobar@yahoo.co.id
}

\author{
Titiek Herwanti² \\ Fakultas Ekonomi dan Bisnis \\ Universitas Mataram, Indonesia.
}

\author{
Lalu M. Furkan ${ }^{3}$ \\ Fakultas Ekonomi dan Bisnis \\ Universitas Mataram, Indonesia.
}

\begin{abstract}
ABSTRAK
Penelitian ini bertujuan untuk menguji dan menemukan bukti empiris mengenai pengaruh partisipasi anggaran, kejelasan sasaran anggaran dan struktur desentralisasi terhadap kinerja Manejerial Satuan Kerja Perngkat Daerah (SKPD).Jumlah sampel 126 responden dari 42 SKPD. Alat analisis yang digunakan dalam penelitian adalah regresi linier berganda, unit analisis dalam penelitian ini adalah Satuan Kerja Perngkat Daerah (SKPD) di Pemerintah Kabupaten Lombok Barat. Hasil penelitian Kejelasan sasan anggaran berpengaruh positif signifikan terhadap kinerja manajerial SKPD. Partisipasi anggaran tidak berpengaruh terhadap kinerja manajerial SKPD. Struktur desentralisasi tidak berpengaruh terhadap kinerja manajerial SKPD.
\end{abstract}

Kata Kunci : Partisipasi; Sasaran Anggaran; Struktur Desentraslisasi.

\section{Effect of Budgeting Participation, Clarity of Budget Goals and Decentralized Structure of Managerial Performance in West Lombok}

\section{ABSTRACT}

This study aims to examine and find empirical evidence regarding the effect of budgetary participation, clarity of budget targets and decentralized structures on the performance of SKPD Management. The number of samples was 126 respondents from 42 SKPD. The analytical tool used in this study is multiple linear regression, the unit of analysis in this study is the Regional Level Work Unit (SKPD) in the West Lombok Regency Government. Research results (1) Clarity of budgetary budget has a significant positive effect on SKPD managerial performance. (2) Budget participation does not affect the SKPD managerial performance. (3) The decentralization structure does not affect the SKPD managerial performance.

Keywords: Budget Participation; Clarity of Budget Goals; Decentralized Structure.

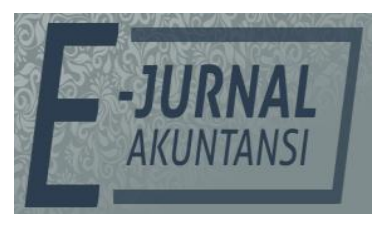

E-JA

e-Jurnal Akuntansi e-ISSN 2302-8556

Vol. 29 No. 2

Denpasar, November 2019

Hal. 658-672

Artikel masuk: 19 Oktober 2019

Tanggal diterima: 18 November 2019 


\section{PENDAHULUAN}

Indonesia telah mencanangkan pelaksanaan anggaran berbasis kinerja sebagaimana disebutkan dalam Peraturan Pemerintah Nomor 21 Tahun 2004 Pasal (7), bahwa setiap kementerian/lembaga negara diharuskan menyusun anggaran dengan mengacu kepada indikator kinerja, standar biaya, dan evaluasi kinerja.Anggaran berbasis kinerja menuntut adanya efektivitas dalam semua pelaksanaan program dan kegiatan pemerintah yang terakomodasi di dalam anggaran (Mardiasmo., 2009:85). Dengan pelaksanaan anggaran berbasis kinerja, pemerintah didorong untuk dapat menggunakan dana secara efisien dan ekonomis, dan dituntut untuk mampu mencapai tujuan yang telah ditetapkan.

Anggaran merupakan alat bantu manajemen dalam mengalokasikan keterbatasan sumber daya alam dan sumber daya dana yang dimiliki organisasi untuk mencapai tujuan. Selain itu, anggaran memiliki karakteristik yang merupakan elemen penting dalam sistem pengendalian manajemen. Schiff dan Lewin., (1970) dalam Sunaryo., (2006)) menemukan bahwa anggaran memiliki dua peranan penting yaitu sebagai perencanaan dan kriteria kinerja. Anggaran sebagai perencanaan berisi tentang rencana-rencana keuangan organisasi di masa yang akan datang, sedangkan anggaran sebagai kriteria kinerja berfungsi sebagai bagian dari proses pengendalian manajemen yang dapat dinyatakan secara formal. Kenis., (1979); Antony \& Govindarajan., (1998) menemukan bahwa anggaran tidak saja sebagai alat perencanaan keuangan dan kinerja tetapi juga sebagai alat pengendalian, koordinasi, komunikasi, evaluasi dan motivasi.

Penganggaran dalam organisasi sektor publik merupakan instrumen akuntabilitas atas pengelolaan dana publik dan pelaksanaan program-program yang dibiayai dengan uang public (Mardiasmo., 2009:61). Secara sederhana dapat dikatakan bahwa anggaran publik menggambarkan kondisi keuangan dari suatu organisasi yang meliputi informasi mengenai pendapatan, belanja dan aktivitas.

Undang-Undang Nomor 32 Tahun 2004 tentang Pemerintah Daerah dan Undang-Undang Nomor 33 Tahun 2004 tentang Perimbangan Keuangan Pemerintah Pusat dan Daerah mendorong adanya desentralisasi penyelenggaraan pemerintah daerah. Desentralisasi ini menunjukkan adanya pelimpahan kewenangan dari pemerintah pusat kepada pemerintah daerah untuk mengatur dirinya secara otonom.Dalam lingkup pemerintahan daerah perubahan paradigma ini tentu saja membawa implikasi terhadap pemerintahan daerah untuk melakukan reformasi dalam penganggaran sehingga pengelolaan keuangan daerah juga harus mengikuti prinsip transparansi, akuntabilitas, value for money dan juga merubah sistem pengelolaan anggaran dari anggaran tradisional menjadi anggaran berbasis kinerja (Cipta., 2011). Hal ini juga telah merubah pertanggungjawaban pemerintah daerah termasuk dengan perangkatperangkat pemerintah daerah yang terkoordinasi dalam badan-badan, dinasdinas, dan perangkat lainnya yang terkait, dari pertanggungjawaban vertikal ke pertanggungjawaban horisontal.Pemerintah Daerah terdiri dari pelaksanapelaksana pemerintah yang disebut dengan SKPD (Satuan Kerja Perangkat Daerah).

Hal ini menyebabkan penelitian di bidang anggaran pada pemerintah daerah menjadi relevan dan penting untuk mewujudkan kinerja SKPD yang lebih baik sesuai dengan fungsi pemerintah itu sendiri sebagai pelayan masyarakat. 
Mardiasmo., (2009:65) menyatakan bahwa anggaran merupakan alat yang efektif untuk pengendalian dan penilaian kinerja. Kinerja dinilai berdasarkan pencapaian target anggaran dan standar efektifitas dan efisiensi pelaksanaan anggaran. Dalam instansi pemerintah daerah hal ini dapat menjadi penilaian dari kinerja SKPD.

Partisipasi penganggaran adalah proses yang menggambarkan individuindividu terlibat dalam penyusunan anggaran dan mempunyai pengaruh terhadap target anggaran dan perlunya penghargaan atas pencapaian target anggaran tersebut (Brownell, 1982). Kenis (1979) menyatakan bahwa salah satu karakteristik sistem penganggaran yaitu partisipasi dalam penyusunan anggaran.Partisipasi anggaran adalah tingkat partisipasi manajer dalam mempersiapkan anggaran dan pengaruh mereka dalam menentukan pencapaian sasaran anggaran di pusat pertanggungjawabannya.

Pemerintah Daerah telah menerapkan partisipasi setiap satuan kerja dalam penyusunan anggaran terkait penyusunan APBD.Masing-masing SKPD memuat Rencana Kerja Anggaran yang biasa disebut RKA SKPD. RKA SKPD di masing-masing SKPD telah memuat indikator kinerja yang akan dicapai untuk setiap program dan kegiatan yang akan dilaksanakan. RKA SKPD telah memuat input, output dan outcome dari masing-masing program dan kegiatan, jadi di dalam RKA SKPD telah memuat sasaran anggaran.

Kejelasan sasaran anggaran akan memberikan kemudahan bagi SKPD untuk menetapkan target anggaran serta mempermudah pelaksana anggaran dalam merealisasikannya. Secara langsung ini akan mempengaruhi kinerja.

Di samping partisipasi penyusunan anggaran, salah satu karakteristik sistem penganggaran adalah kejelasan sasaran anggaran.Kejelasan sasaran anggaran membantu pegawai untuk mencapai kinerja yang diharapkan.Kejelasan sasaran anggaran merupakan sejauh mana tujuan anggaran ditetapkan secara jelas dan spesifik dengan tujuan agar anggaran tersebut dapat dimengerti oleh orang yang bertanggung jawab atas pencapaian sasaran anggaran tersebut. Dengan adanya sasaran anggaran yang jelas, aparat pelaksana anggaran juga akanlebih mudah dalam merealisasikannya, secara tidak langsung ini akan mempengaruhi terhadap kinerja aparat. Salah satu penyebab tidak efektif dan efisiennya anggaran dikarenakan ketidakjelasan sasaran anggaran yang mengakibatkan aparat pemerintah daerah mengalami kesulitan dalam penyusuanan target-target anggaran (Kenis., 1979) dalam ( Syafrial., 2009).

Struktur desentralisasi secara umum ditujukan dengan pengambilan keputusan yang terjadi dalam organisasi. Dalam struktur sentralisasi yang tinggi, sebagian keputusan diambil pada tingkat hirarki organisasi yang tertinggi, dan apabila sebagian otorisasi didelegasikan pada level yang rendah dalam organisasi, maka organisasi tersebut lebih desentralisasi.

Penomena yang terjadi dalam pemerintahan Lombok Barat khususnya Pada tahun anggaran 2017, bahwa terdapat pokok-pokok ketidak patuhan yang ditemukan BPK RI Perwakilan NTB di Kabupaten Lombok Barat yakni yang pertama, Pembayaran Belanja Tunjangan Pegawai senilai Rp69.126.000,00; tidak sesuai ketentuan. Yang Kedua, Kekurangan Volume atas 13 Paket Pekerjaan pada Empat OPD senilai Rp1.318.123.199,00; yang ketiga, Kekurangan Pemotongan 
PPh Pasal 4 ayat 2 senilai Rp64.513.063,82; dari Pelaksana Jasa Konstruksi. Yang Keempat, pengelolaan belanja bantuan keuangan Dana Desa dan Alokasi Dana Desa senilai Rp80.371.586,58; tidak sesuai ketentuan. Dan yang kelima, belanja perjalanan dinas pada 21 OPD senilai Rp1.544.996.070,00; tidak sesuai ketentuan.

Sedangkan untuk tahun anggaran 2018, Berdasarkan pemeriksaan yang dilakukan BPK, masih terdapat kelemahan atas kepatuhan terhadap perundangundangan dan kelemahan yang dapat mempengaruhi efektivitas pengelolaan belanja modal daerah dan Dana Desa (DD) serta Alokasi Dana Desa (ADD). Ada beberapa hal yang dicatat dalam LHP antara lain bendahara desa tidak memungut atau menyetorkan pajak sesuai ketentuan, kemahalan harga atas pekerjaan barang dan jasa, kekurangan volume pekerjaan fisik, pemebebasan tanah yang tidak sesuai dengan kondisi senyatanya, dan lainnya," jelas Kepala BPK RI Perwakilan NTB, Hery Pruwanto usai menyerahkan LHP.

Berdasarkan fenomena di atas dan peneliti termotivasi untuk meneliti lebih lanjut tentang hubungan partisipasi anggaran, kejelasan sasaran anggaran dan struktur organisasi yang terdesentralisasi dengan kinerja manajerial pemerintah daerah.

Penelitian mengenai hubungan antara partisipasi dalam proses penyusunan anggaran terhadap kinerja manajerial merupakan penelitian yang masih banyak diperdebatkan. Beberapa penelitian mengenai hubungan antara partisipasi penyusunan anggaran dengan kinerja manajerial menunjukkan hasil yang tidak konsisten; Brownell dan McInnes .,(1986), Kewo., (2014), Fibrianti dan Riharjo., (2013), Nurhalimah (2013), Soetrisno., (2010), Istiyani., (2009), Maisyarah (2008), Sembiring., (2008) dan Sardjito dan Muntaher., (2007)) menemukan hubungan positif dan signifikan antara partisipasi penyusunan anggaran dan kinerja manajerial. Berbeda dengan penelitian yang telah dilakukan Milani., (1975); Brownell \& Hirst., (1986) dalam Sukardi., (2004), Sumarno., (2005) dimana mereka menemukan hasil yang tidak signifikan antara partisipasi penyusunan anggaran dengan kinerja manajerial.

Penelitian sebelumnya terkait kejelasan sasaran anggaran yang pernah dilakukan dan memberikan hasil yang berbeda, antara lain penelitian Emilia dkk. (2013) menyatakan bahwa kejelasan sasaran anggaran memiliki pengaruh terhadap akuntabilitas kinerja instansi pemerintah. Anjarwati., (2012) juga menyatakan bahwa kejelasan sasaran anggaran memiliki pengaruh terhadap akuntabilitas kinerja instansi pemerintah. Penelitian Abdullah., (2004) yang mengatakan terdapat hubungan yang signifikan antara kejelasan sasaran anggaran dengan akuntabilitas kinerja instansi pemerintah.Namun demikian terdapat ketidakkonsistenan hasil penelitian. Penelitian Bangun., (2009) menunjukkan kejelasan sasaran anggaran tidak berpengaruh secara signifikan terhadap kinerja manajerial. Penelitian Herawaty., (2011) menunjukkan bahwa kejelasan sasaran anggaran memiliki pengaruh negatif terhadap akuntablitas kinerja instansi pemerintah. Dari beberapa penelitian diatas bahwa kejelasan sasaran anggaran berpengaruh terhadap akuntabilitas kinerja, sedangkan kebaruan penelitian ini dengan penelitian sebelumnya beberapa variabel tidak menjelaskan pengaruh variabel yang lain. Apakah terdapat pengaruh partisipasi dalam penyusunan anggaran terhadap kinerja menejerial SKPD ?. Apakah terdapat pengaruh Kejelasan Sasaran Anggaranterhadap kinerja menejerial SKPD 
?. Apakah terdapat pengaruh struktur Desentralisasi terhadap kinerja menejerial SKPD?

Berdasarkan rumusan masalah di atas, maka tujuan dalam penelitian ini adalah Untuk menganalisis pengaruh partisipasi dalam penyusunan anggaran terhadap kinerja menejerial SKPD. Untuk menganalisis pengaruh Kejelasan Sasaran Anggaran terhadap kinerja menejerial SKPD. Untuk menganalisis pengaruh Desentralisasi terhadapkinerja menejerial SKPD?

Adapun Grand Theory yang mendasari penelitian, yaitu: agency theory landasan teori dalam penelitian ini menjelaskan konsep corporate governance dimana konsep ini lebih kepada aspek akuntabilitas yang meliputi cara kerja, aturan dan cara pengambilan keputusan serta penerapannya kepada masyarakat. Menurut Jensen \& Meckling., (1976) teori keagenan adalah konsep yang menjelaskan hubungan kontraktual antara principal dan agen, yaitu antara dua atau lebih individu, kelompok atau organisasi. Pihak principal adalah pihak yang mengambil keputusan dan memberikan mandat kepada pihak lain (agen), untuk melakukan semua kegiatan atas namaprincipal. Inti dari teori ini adalah kontrak kerja yang didesain dengan tepat untuk menyelaraskan kepentingan antara principal dengan agen ( Sinkey, 1992; Supanto, 2010).

Anggaran sektor publik berhubungan dengan proses penentuan jumlah dana untuk tiap-tiap program dan aktivitas dalam satuan moneter yang menggunakan dana milik rakyat, serta bersifat terbuka untuk publik. Menurut Eisenhard., (1989) ada tiga asumsi mengenai teori keagenan, yaitu: 1) asumsi tentang sifat manusia, yaitu sifat manusia yang mengutamakan kepentingan sendiri (self interest), keterbatasan rasionalitas atau daya pikir terhadap persepsi masa depan (bounded rationality), dan cenderung untuk menghindari resiko; 2) asumsi tentang keorganisasian, adalah konflik antar anggota organisasi, efisiensi, dan asimetri informasi yang terjadi antara principal dan agen; dan 3) asumsi tentang informasi, adalah informasi dianggap sebagai barang komoditi yang dapat diperjualbelikan. Berdasarkan ketiga asumsi tersebut manusia akan bertindak opportunistik, yaitu mengutamakan kepentingan pribadi daripada kepentingan organisasi. Agenakan termotivasi untuk meningkatkan kompensasi dan jenjang karir di masa mendatang, sedangkan principal termotivasi untuk meningkatkan utilitas dan profitabilitasnya. Konflik kepentingan antara agen dan principalakan terus meningkat, karena principal tidak dapat memonitor kegiatan agen setiap hari. Sebaliknya, agen memiliki lebih banyak informasi penting mengenai kapasitas diri, lingkungan kerja dan organisasinya secara keseluruhan.Hal inilah yang menimbulkan asimetri informasi yaitu ketidakseimbangan informasi antara principal dan agen.

$\mathrm{H}_{1}$ : Partisipasi anggaran berpengaruh positif terhadap efektifitas anggaran.

Kenis., (1979) mengemukakan bahwa konsep partisipasi anggaran adalah tingkat partisipasi manajer dalam mempersiapkan anggaran dan pengaruh mereka dalam menentukan pencapaian sasaran anggaran di pusat pertanggungjawabannya. Kenis., (1979) juga mengemukakan karakteristik tujuan anggaran yang salah satunya adalah partisipasi penyusunan anggaran, hal ini sejalan dengan penelitian Sunaryo., (2006) yang menemukan bahwa variabel karakteristik anggaran berpengaruh positif terhadap efektifitas anggaran dan pengaruh yang paling dominan dalam karakteristik tersebut adalah partisipasi 
penyusunan anggaran. Murtiyani (2001) menunjukkan adanya pengaruh sistem penganggaran terkait efektifnya suatu anggaran.

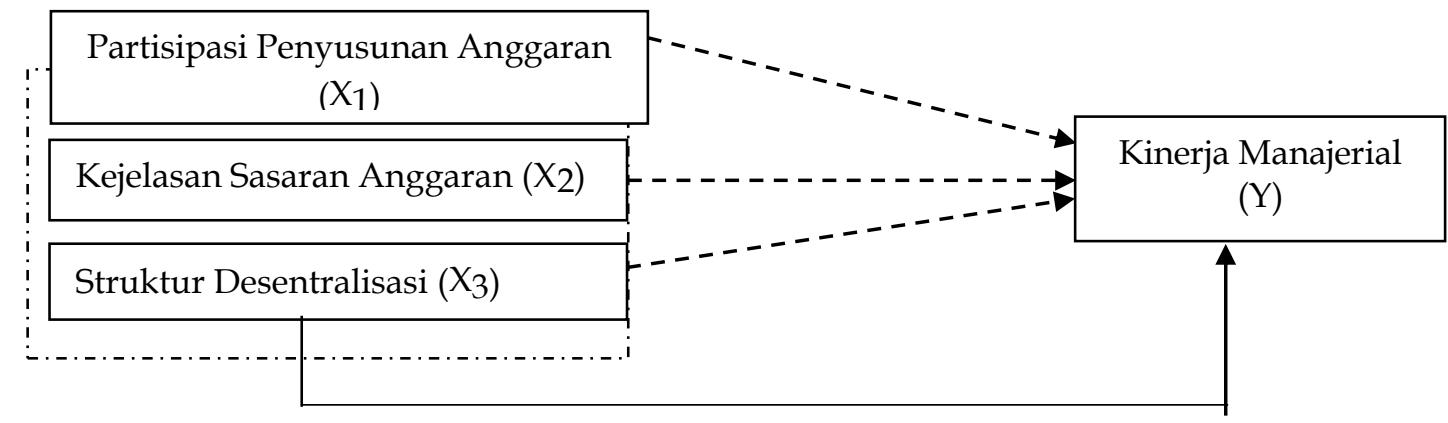

Gambar 1. Rerangka Konseptual

Sumber : Data Penelitian 2019,

Partisipasi anggaran memiliki peran yang sangat penting untuk meningkatkan efektifitas dan efisiensi anggaran serta dapat menghasilkan keputusan dengan kualitas yang tinggi (Sabas., 2011). Setiap anggota atau aparat dalam organisasi diberikan tanggungjawab terhadap keputusan yang dihasilkan bersama untuk peningkatan tujuan organisasi dan akhirnya mampu meningkatkan kinerja. Santoso., (2009) menunjukkan bahwa partisipasi anggaran dan profesionalisme aparat berpengaruh secara signifikan terhadap efektifitas anggaran. Hal ini juga sejalan dengan penelitian yang dilakukan Yeyen., (2013) yang menyatakan bahwa partisipasi anggaran berpengaruh positif signifikan terhadap pencapaian anggaran yag efektif.

Penelitian yang dilakukan oleh Jasman., (2012) menemukan bahwa partisipasi anggaran berpengaruh positif tapi tidak signifikan terhadap efektifitas pengelolaan anggaran, hal ini disebabkan karena objek penelitian hanya pada satu organisasi yang memiliki data relatif kecil. Penelitian lain oleh Alim., (2008) menemukan bahwa partisipasi anggaran tidak berpengaruh terhadap sasaran anggaran dimana sasaran anggaran ini juga tidak berpengaruh terhadap kinerja, jadi dapat dikatakan bahwa partisipasi anggaran tidak berpengaruh terhadap kinerja. Hal ini disebabkan karena adanya partisipasi semu dimana keterlibatan manajer dalam penyusunan anggaran tidak berpengaruh atau tidak ada kontribusi terhadap sasaran anggaran.

$\mathrm{H}_{2}$ : Kejelasan sasaran anggaran berpengaruh terhadap kinerja manajerial.

Locke, et al., (1981) menyatakan bahwa sasaran adalah apa yang hendak dicapai oleh karyawan dan kejelasan sasaran anggaran akan mendorong manajer lebih efektif dan melakukan yang terbaik jika dibandingkan dengan sasaran yang tidak jelas. Kejelasan sasaran anggaran adalah sejauh mana anggaran ditetapkan secara jelas, spesifik, rinci, terukur, dan dapat dicapai.

Teori keagenan menyatakan bahwa antara agen (kepala SKPD) sering terjadi ketidak seimbangan informasi dengan pihak principal (Pejabat Struktural) yang diakibatkan karena suatu kepentingan pada masing-masing.Hal tersebut biasanya dikenal dengan istilah asimetri informasi.asimetri informasi merupakan suatu kondisi ketidak seimbangan dalam memperoleh informasi antara pihak manajemen sebagai penyedia informasi (prepaper) dengan pihak pemegang saham sebagai pengguna informasi (user). Adanya sasaran yang jelas akan memudahkan penyusunan target-target anggaran dan mempermudah kepala 
sekolah untuk mempertanggungjawabkan keberhasilan atau kegagalan pelaksanaan tugas sekolah dalam rangka mencapai tujuan dan sasaran yang telah ditetapkan sebelumnya sehingga akan meningkatkan akuntabilitas kinerja sekolah. Anggaran harus bisa menjadi tolok ukur pencapaian akuntabilitas kinerja yang diharapkan sehingga perencanaan anggaran bisa menggambarkan sasaran anggaran secara jelas.

Penelitian Kusuma, (2013) membuktikan bahwa kejelasan sasaran anggaran berpengaruh positif terhadap ketepatan anggaran.Artinya, semakin besar kejelasan sasaran anggaran yang diberikan, maka semakin tinggi pula tercapainya ketepatan anggaran pendapatan dan belanja di SKPD Pemerintah Bali. Penelitian lain yang dilakukan oleh Istiyani (2009) membuktikan bahwa terdapat pengaruh yang positif dan signifikan antara variabel kejelasan sasaran anggaran terhadap kinerja aparat Pemda. Hal ini berarti, semakin jelas tujuan anggaran maka semakin tinggi kinerja aparat pemda dalam melaksanakan tugas dan tanggungjawabnya.Berbeda dengan Kusuma (2013) dan Istiyani (2009) hasil penelitian Nurhalimah (2013) menunjukkan bahwa kejelasan sasaran anggaran tidak berpengaruh terhadap kinerja aparatur perangkat daerah di Pemerintah Aceh.

$\mathrm{H}_{3}$ :Semakin tinggi struktur desenteralisasi semakin tinggi tingkat kinerja aparat pemerintah daerah.

Desentralisasi merupakan pendelegasian wewenang dari jenjang yang lebih tinggi ke jenjang lebih rendah untuk mengambil kebijakan secara independen.Tingginya tingkat desentralisasi merupakan bentuk yang tepat untuk menunjangpencapaian kinerja manajerial yang lebih baik. Pengertian desentralisasi pada dasarnya mempunyai makna bahwa melalui proses desentralisasi urusan-urusan pemerintahan yang semula termasuk wewenang dan tanggung jawab Pemerintah pusat sebagian diserahkan kepada badan/lembaga pemerintah daerah agar menjadi urusan rumah tangganya sehinggga urusan tersebut beralih kepada dan menjadi wewenang dan tanggung jawab daerah.

Syafruddin, (2005) meneliti pengaruh moderasi faktor inovasi pada hubungan partisipasi anggaran struktur terdesentralisasi dan kinerja manajemen (studi di organisasi pemerintahan daerah), Variabel independen yang digunakan dalam penelitian tersebut adalah Struktur organisasi terdesentralisasi $\left(X_{1}\right)$ dan partisipasi anggaran $\left(X_{2}\right)$ dan Variabel Dependen yang diguanakan adalah Faktor Komitmen Organisasi serta Variabel moderating adalah faktor inovasi manajemen, hasil dari penelitian tersebut menyatakan bahwa pemberian kesempatan pada karyawan pemda untuk berpartisipasi dan pendelegasian wewenang dalam proses penetapan APBD meruapakan hal yang penting (necessary) tetapi ini saja belum cukup (sufficient).Ada faktor lain yang harus diperhatikan adalah faktor yang mampu membangkitkan motivasi dan membangkitkan daya kognitif mereka, faktor-faktor pemoderasi lain seperti kompleksitas tugas, gaya kepemimpinan, teknik evaluasi oleh pimpinan, struktur penghargaan, fokus control karyawan dan lainnya. 


\section{METODE PENELITIAN}

Jenis penelitian yang digunakan dalam penelitian ini adalah penelitian asosiatif, yaitu suatu penelitian yang mencari hubungan antara satu variabel dengan variabel lain. Hubungan yang digunakan dalam penelitian ini adalah hubungan kausal yang bersifat sebab-akibat, dimana terdapat variabel yang dipengaruhi (variabel dependent) dan variabel-variabel yang mempengaruhi (variabel independent) (Sugiyono, 2013:11). Peneliti menggunakan desain penelitian ini untuk memberikan bukti empiris dan menganalisis partisipasi penyusunan anggaran, kejelasan sasaran anggaran dan struktur desentralisasi sebagai variabel independen terhadap kinerja manajerial SKPD sebagai variabel dependen dengan pada Pemerintah Kabupaten Lombok Barat. Lokasi penelitian yaitu seluruh SKPD dilingkungan Pemerintah Kabupaten Lombok Barat dan dibatasi pada kinerja manajerial SKPD dalam penyusunan anggaran SKPD yaitu Kepala Satuan Kerja selaku pengguna anggaran dan Pejabat Penata usahaan Keuangan. Sedangkan rencana waktu penelitian yakni selama 12 Minggu (Februari s.d April 2019). Populasi dalam penelitian ini adalah pejabat struktural dan pegawai yang terlibat dalam penyusunan anggaran SKPD yang berjumlah 126 orang dari 42 SKPD pada Pemerintah Kabupaten Lombok BArat. Teknik pengambilan sampel menggunakan non probability sampling, dengan menggunakan metode sensus, yaitu teknik penentuan sampel bila semua anggota populasi digunakan sebagai sampel (Sugiyono, 2013:85). Dengan kriteria bahwa responden adalah pejabat yang terlibat langsung dalam penyusunan rencana kerja dan anggaran yaitu terdiri dari Kepala Dinas/Badan/Kantor (KPA), 1 Kabid/Kasubag/Kasi (PA) dan Pengelola Keuangan/Bendahara, sehingga jumlah seluruh responden dari 42 SKPD di Pemerintah Lombok Barat berjumlah 126 orang responden.

Variabel independen $(X)$ yaitu variabel yang tidak dipengaruhi oleh variabel lainnya dalam model penelitian. Variabel independen dalam penelitian ini adalah Partisipasi anggaran $\left(X_{1}\right)$, Kejelasan Sasaran anggaran $\left(X_{2}\right)$, Struktur Desentralisasi $\left(X_{3}\right)$. Variabel dependen yaitu variabel yang dipengaruhi oleh variabel lain dalam model penelitian. Variabel dependen dalam penelitian adalah Kinerja SKPD (Y).

$$
\mathrm{Y}=\mathrm{a}+\mathrm{b} 1 \mathrm{X} 1+\mathrm{b} 2 \mathrm{X} 2+\mathrm{b} 3 \mathrm{X} 3+\varepsilon
$$

Prosedur analasis data yang digunakan dalam penelitian ini yaitu dilakukan dengan cara melakukan perhitungan sehingga setiap rumusan masalah dapat ditemukan jawabannya secara kuantitatif. Dalam penelitian ini, analisis data dihitung dengan menggunakan software SPSS. Adapun persamaan model regresi secara sistematis sebagai berikut:

$$
\mathrm{EA}=\alpha+\beta 1 \mathrm{PA}+\beta 2 \mathrm{PP}+\beta 3 \mathrm{AI}+e .
$$

Keterangan:

$$
\begin{array}{ll}
\mathrm{A} & =\text { Konstanta } \\
\mathrm{EA} & =\text { Efektifitas Anggaran SKPD } \\
\mathrm{PA} & =\text { Partisipasi Anggaran } \\
\mathrm{PP} & =\text { Pemahaman Penyusun RKA } \\
\mathrm{AI} & =\text { Asimetri Informasi } \\
\beta 1,2.3 & =\text { Koefisien Regresi } \\
e & =\text { error }
\end{array}
$$




\section{HASIL DAN PEMBAHASAN}

Pengujian asumsi klasik dalam penelitian ini terdiri dari : Uji normalitas, uji multikolinieritas, dan heterokedastisitas. Untuk lebih jelasnya dapat diuraikan sebagai berikut:

Hasil uji normalitas menunjukkan bahwa data terdistribusi normal, dengan melihat nilai Kolmogrof Smirnov dan masing-masing variabel tidak signifikan pada 0,05 , karena probability lebih besar dari 0.05 . Hal ini berarti $\mathrm{H}_{0}$ diterima yang berarti data terdistribusi secara normal.Pengujian normalitas data dapat lihat pada Tabel 1.

\section{Tabel 1. Uji Normalitas}

\begin{tabular}{ll}
\hline & Unstandarized Residual \\
\hline $\mathrm{N}$ & 117 \\
Kolmogorov-Smirnov Z & 0,059 \\
Asymp. Sig. (2-tailed) & 0,200 \\
\hline
\end{tabular}

Sumber: Data Penelitian, 2019

Nilai probabilitas kesalahan statistik Kolomogorov Smirnov untuk variabel residu model pengaruh Partisipasi Anggaran (X1), Kejelasan sasaran anggaran (X2) dan Struktur Desentralisasi (X3) terhadap Kinerja Manajerial SKPD (Y) adalah sebesar 0,059. Data dinyatakan normal apabila memiliki nilai signifikansi diatas 0,005.Dari hasil di atas diputuskan bahwa variabel residu model berdistribusi normal.

Uji multikolinearitas dilakukan dengan menggunakan nilai VIF (Variance Inflation Faktor).Nilai VIF mengindikasikan tingkat keeratan hubungan antara suatu variabel bebas dengan variabel bebas lainnya.

Tabel 2. Pengujian Multikolinearitas

\begin{tabular}{lll}
\hline Model & \multicolumn{2}{l}{ Collinearity Statistics } \\
& Tolerance & VIF \\
\hline Partisipasi Anggan (X1) & 0,955 & 1,048 \\
KejelasanSasaranAnggaran (X2) & 0,942 & 1,061 \\
StrukturDesentralisasi (X3) & 0,951 & 1,0516 \\
\hline
\end{tabular}

Sumber: Data Penelitian, 2019

Dari hasil analisis diperoleh nilai VIF yang kurang dari 10.VIF untuk X1 = 1,048, untuk X2 = 1,061 dan untuk X3 = 1,051 (VIF < 10).Dapat disimpulkan bahwa tidak terjadi situasi multikolonieritas dalam model.

Uji heteroskedastisitas dilakukan dengan menggunakan Uji Glejseryang digunakan untuk mendeteksi terjadi atau tidaknya heteroskedastisitas. Uji Glejser berwujud regresi nilai absolut residual terhadap variabel Independent.

Tabel 3. Pengujian Heterokedastisitas

\begin{tabular}{ll}
\hline Variabel Independen & Sig. \\
\hline Partisipasi Anggan & 0,615 \\
KejelasanSasaranAnggaran & 0,656 \\
StrukturDesentralisasi & 0,495 \\
\hline
\end{tabular}

Sumber: Data Penelitian, 2019

. Hasil uji menunjukkan untuk variabel independent dengan nilai $\mathrm{N}=117$ dan $\mathrm{t}=0,025$ maka $\mathrm{t}$ tabel $=1,981$, sehingga berdasarkan $\mathrm{t}$ hitung $<\mathrm{t}$ tabel dan nilai sig $>0,05$ maka dapat disimpulkan data tidak terjadi heteroskedastisitas yang bersifat merusak model. Tidak adanya heteroskedastisitas yang merusak 
model juga ditunjukkan oleh gambar 1 dimana sebaran data cenderung membentuk pola acak atau tidak membentuk pola tertentu yang teratur.

Tabel 4. Analisis Regresi Linier Berganda

\begin{tabular}{lll}
\hline Model & $\beta$ & $\mathrm{T}$ \\
\hline Constant & 8,535 & 5,069 \\
Partisipasi Anggaran & 0,005 & 0,062 \\
Kejelasan Sasaran Anggaran & 0,181 & 3,824 \\
Struktur Desentralisasi & 0,100 & 1,078 \\
\hline
\end{tabular}

Sumber: Data Penelitian, 2019

Persamaan regresi pengaruh Partisipasi Anggaran (X1), Kejelasan Sasaran Anggaran (X2) dan Struktur Desentralisasi (X3) terhadap Kinerja Manajerial SKPD (Y) sebagai berikut:

$$
Y=8,535+0,005 X 1+0,181 X 2+0,100 X 3+\varepsilon
$$

Berdasarkan tabel di atas, dapat dilihat nilai beta $(\beta)$ di setiap variabel bernilai positif maka semua variabel independent searah. Dalam menentukan pengaruh dapat dilihat melalui nilai Sig, dimana apabila nilai Sig $<0,05$ maka hanya variabel Kejelasan Sasaran Anggaran (X2) yang berpengaruh signifikan dengan arah pengaruh yang positif. Hal ini dapat juga dilihat dengan $t$ tabel $=$ 1,981. Sehingga dapat dijelaskan bahwa jika $t$ hitung $>t$ tabel, maka berdasarkan tabel diatas variabel Partisipasi Anggaran (X1) 0,062 > 1,982, hal ini menunjukkan bahwa variabel Partisipasi Anggaran tidak berpengaruh.Begitu juga dengan variabel Struktur Desentralisasi (X3) yang menunjukkan 1,078 > 1,982 yang berarti bahwa variabel Struktur Desentralisasi (X3) tidak berpengaruh.Beda halnya dengan variabel Kejelasan Sasaran Anggaran yaitu 3,824 > 1,982, artinya bahwa variabel Kejelasan Sasaran Anggaran berpengaruh.

Tabel 5. Nilai Koefisien Determinasi

\begin{tabular}{cll}
\hline $\mathrm{R}$ & $\mathrm{R}$ & Adjusted R Square \\
& Square & \\
\hline $0,222^{\mathrm{a}}$ & 0,049 & 0,024 \\
\hline
\end{tabular}

Sumber: Data Penelitian, 2019

Ringkasan model, sebagaimana ditunjukkan oleh koefisien korelasi berganda (R) seperti tabel 5, diperoleh derajat pengaruh antara Partisipasi Anggaran, Kejelasan Sasaran Anggaran dan Struktur Desentralisasi terhadap Kinerja Manajerial SKPD sebesar 0,222, ini mengindikasikan bahwa secara simultan atau bersama-sama memiliki pengaruh hanya sebesar $4,90 \%\left(\mathrm{R}^{2}=\right.$ 0,049), artinya kemampuan Partisipasi Anggaran, Kejelasan Sasaran Anggaran dan Struktur Desentralisasi mempengaruhi Kinerja SKPD di Pemerintah Kabupaten Lombok Barat hanya sebesar 4,90\% sedangkan sisanya sebesar 95,1\% dipengaruhi oleh variabel lain di luar penelitian ini.

Untuk mengetahui signifikansi pengaruh secara parsial dicari dulu $t$ hitung kemudian dibandingkan $\mathrm{t}$ tabel dengan kaidah pengujian. Bila $\mathrm{t}$ hitung $>\mathrm{t}$ tabel maka Ho ditolak, artinya tidak signifikan $\mathrm{t}$ tabel $=\mathrm{t}(\mathrm{a}=0,05$ 1-sisi; $\mathrm{db}=\mathrm{n}-\mathrm{k}-$ $1=117-3-1=113)=1,982$. 
Tabel 6. Uji Signifikansi Pengaruh Parsial

\begin{tabular}{|c|c|c|}
\hline Model & $\begin{array}{l}\text { Unstandardized Coefficients } \\
\text { B }\end{array}$ & Sig. \\
\hline Constant & 19.601 & 0,000 \\
\hline Partisipasi Anggaran & 0,012 & 0,862 \\
\hline KejelasanSasaranAnggaran & 0,167 & 0,022 \\
\hline StrukturDesentralisasi & $-0,005$ & 0,957 \\
\hline
\end{tabular}

Sumber: Data Penelitian, 2019

Berdasarkan tabe 6 perhitungan SPSS, varaibel partisipasi anggaran nilai. Secara empirik, Partisipasi Anggaran di SKPD Pemerintah Kabupaten Lombok Barat tidak memiliki pengaruh terhadap Kinerja Manajerial SKPD.Lemahnya Partisipasi Anggaran pada SKPD di Pemerintah Kabupaten Lombok Barat terletak pada pengaruh dalam menentukan pencapaian dan penetapan sasaran anggaran.Dalam teori agensi hubungan kontraktual antara principal dan agen. Pihak principal dalam hal ini adalah kepala SKPD sebagai pihak yang memberikan mandat kepada pihak lain yaitu agen yang dalam hal ini adalah pejabat struktural di bawah kepala SKPD (Kabid/Kasubag/Kasi) untuk melakukan semua kegiatan atas nama principal dalam kapasitasnya sebagai pengambil keputusan.

Hasil penelitian ini memberikan penjelasan yang amat berharga dalam upaya meningkatkan Kinerja Manajerial SKPD.Dalam konteks organisasi SKPD, Partisipasi Anggaran ini merupakan faktor yang kurang penting dalam meningkatkan Kinerja Manajerial SKPD. Dengan demikian penelitian ini tidak dapat menjawab hipotesis yang diajukan.Hasil penelitian ini sejalan dengan penelitian Alim, (2008) yang mengatakan bahwa partisipasi anggaran yang merupakan salah satu komponen anggaran dalam prosedur anggaran yang saling terkait antar komponen anggaran.Partisipasi dalam penyusunan anggaran membuat para pelaksana anggaran kurang memahami masalah-masalah yang mungkin timbul pada saat pelaksanan anggaran, sehingga partisipasi dalam penyusunan anggaran kurang dapat meningkatkan efektifitas anggaran.

Kejelasan sasaran anggaran nilai sig sebesar 0,022 lebih kecil dari 0,05 Secara empirik, Kejelasan sasaran anggaran di Pemerintah Kabupaten Lombok Barat memiliki pengaruh yang positif dan signifikan terhadap Kinerja Manajerial SKPD.Hal ini ditunjukkan dengan derajat pengaruh secara parsial yang kuat dari Kejelasan sasaran anggaranterhadap Kinerja Manajerial SKPD, yaitu dengan koefisien korelasi parsial sebesar 0,167.

Keunggulan Kejelasan sasaran anggaran dalam menyusun anggaran di Pemerintah Kabupaten Lombok Barat terletak pada dimensi pemahaman mengenai persiapan dan penyusunan anggaran (Budget Praparation). Dalam teori agensi roses penyusunan anggaran partisipatif yang dapat ditelaah dalam aplikasi teori agency terkait penyusunan RKA di lingkup SKPD yaitu hubungan principal yaitu kepala SKPD (Kepala Badan/Dinas/Kantor) dan agen yang dalam hal ini adalah pejabat struktural dibawah kepala SKPD (Kabid/Kaban/Kasi). Pihak principaldan agen memiliki kepentingan masing-masing sehingga benturan atas kepentingan ini memiliki potensi yang selalu terjadi setiap saat. Pihak agen berkemampuan untuk lebih menonjolkan kepentingannya karena memiliki informasi yang lebih dibandingkan pihak principal, hal ini disebabkan karena 
pihak agen yang memegang kendali operasional di lapangan, sehingga pihak agen lebih memilih alternatif yang menguntungkannya dengan mengelabui dan membebankan kerugian pada pihak principal.

Hasil penelitian ini memberikan penjelasan yang amat berharga dalam upaya meningkatkan Kinerja Manajerial SKPD. Dalam konteks organisasi SKPD, Kejelasan sasaran anggaran di Pemerintah Kabupaten Lombok Barat ini merupakan faktor penting dalam meningkatkan Kinerja Manajerial SKPD.Dengan demikian, penelitian ini dapat menjawab hipotesis yang diajukan bahwa Kejelasan sasaran anggaran memberikan pengaruh parsial yang positif dan signifikan terhadap Kinerja Manajerial SKPD.Hasil penelitian ini sejalan dengan penelitian yang dilakukan oleh Sabas, (2011) yang menyatakan bahwa Kejelasan sasaran anggaran secara signifikan berpengaruh positif terhadap Kinerja Manajerial SKPD.

Struktur Desentralisasi memiliki nilai sig 0,957 lebih besar dari 0,05 Secara empirik Secara empirik, Struktur Desentralisasi tidak memiliki pengaruh yang positif dan signifikan terhadap Kinerja Manajerial SKPD di Pemerintah Kabupaten Lombok Barat. Hal ini ditunjukkan dengan derajat pengaruh secara parsial yang lemah dari Struktur Desentralisasi terhadap Kinerja Manajerial SKPD yaitu dengan koefisien korelasi parsial sebesar $-0,054$.

Temuan dalam penelitian ini mengindikasikan tidak adanya Struktur Desentralisasi dalam menyusun anggaran.Struktur Desentralisasi ini merupakan salah satu hal yang tidak perlu ada dalam upaya meningkatkan Kinerja Manajerial SKPD.Dalam konteks organisasi SKPD, Struktur Desentralisasi merupakan faktor yang tidak terlalu berpengaruh dalam meningkatkan Kinerja Manajerial SKPD.Dengan demikian, penelitian ini tidak dapat menjawab hipotesis yang diajukan bahwa Struktur Desentralisasi memberikan pengaruh parsial yang negatif terhadap Kinerja Manajerial SKPD. Hasil penelitian ini tidak sejalan dengan penelitian yang dilakukan oleh Aprila \& Hidayani, (2012) yang menyatakan bahwa Struktur Desentralisasi berpengaruh positif terhadap kesenjangan anggaran dimana hal ini merupakan salah satu ciri yang mendorong tidak terjadinya efektifitas anggaran.

Untuk mengetahui signifikansi pengaruh simultan dicari dulu $\mathrm{F}$ hitung kemudian dibandingkan dengan $\mathrm{F}$ tabel dengan kaidah pengujian.Bila $\mathrm{F}$ hitung> $\mathrm{F}$ tabel maka Ho ditolak, artinya signifikan. Bila $\mathrm{F}$ hitung $\leq \mathrm{F}$ tabel maka Ho diterima, artinya tidak signifikan $\mathrm{F}$ tabel $=\mathrm{F}(\mathrm{a}=0,05 ; \mathrm{db} 1=\mathrm{k}=2 ; \mathrm{db} 2=\mathrm{n}-\mathrm{k}-1=$ $117-3-1=113)=2,69$

Tabel 7. Uji Signifikansi Pengaruh Simultan

\begin{tabular}{lll}
\hline Model & F & Sig. \\
\hline Regression & 1,959 & $0,124^{\mathrm{b}}$ \\
\hline
\end{tabular}

Sumber: Data Penelitian, 2019

Berdasarkan tabel perhitungan SPSS di atas, ternyata F hitung lebih besar daripada F tabel atau7,869> 2,69: maka Ha diterima, Ho ditolak. Secara empiris, Partisipasi Anggaran, Kejelasan sasaran anggaran dan Struktur Desentralisasi di Pemerintah Kabupaten Lombok Barat memiliki pengaruh simultan yang signifikan terhadap Kinerja Manajerial SKPD.Dari 3 (tiga) variabel (partisipasi anggaran, Kejelasan sasaran anggaran dan Struktur Desentralisasi) yang diuji, 
Kejelasan sasaran anggaran mempunyai nilai sig yang paling kecil. Hal ini mengindikasikan bahwa responden paling banyak yang sependapat dengan pernyataan yang dibuat peneliti yaitu bahwa Kejelasan sasaran anggaran dalam mencapai efektifitas anggaran harus selalu memeperhatikan tahapan-tahapan dalam penyusunan anggaran terutama dalam proses persiapan dan penyusunan anggaran (budget preparation).

Kondisi ini sesuai dengan teori agensi dimana pihakprincipal yaitu kepala SKPD dalam menghasilkan anggaran yang efektif melakukan hubungan kontraktual dengan agen yaitu dalam hal ini adalah pejabat struktural (Kabid/Kasubag/Kasi) yang melakukan semua kegiatan atas nama principal dalam penyusunan anggaran SKPD di Kabupaten Lombok Barat. Hasil penelitian ini mendukung hasil penelitian Sabas, (2010) yang menemukan bahwa partisipasi anggaran dan Kejelasan sasaran anggaran berpengaruh signifikan terhadap Kinerja Manajerial SKPD.

Hasil penelitian ini memberikan penjelasan yang amat berharga dalam upaya meningkatkan Kinerja Manajerial SKPD. Dalam konteks organisasi SKPD, Partisipasi Anggaran, Kejelasan sasaran anggaran dan Struktur Desentralisasi di Pemerintah Kabupaten Lombok Barat merupakan faktor yang cukup penting dalam meningkatkan Kinerja Manajerial SKPD di Pemerintah Kabupaten Lombok Barat. Dengan demikian penelitian ini dapat menjawab hipotesis yang diajukan bahwa Partisipasi Anggaran, Kejelasan sasaran anggarandan Struktur Desentralisasi memberikan pengaruh simultan yang signifikan terhadap Kinerja Manajerial SKPD di Pemerintah Kabupaten Lombok Barat.

\section{SIMPULAN}

Partisipasi anggaran tidak berpengaruh terhadap Kinerja manajerial SKPD di Pemerintah Kabupaten Lombok Barat.Kejelasan sasaran anggaran dalam penyusunan anggaran memiliki pengaruh parsial yang positif secara signifikan terhadap Kinerja manajerial SKPD.Struktur Desentralisasi tidak memiliki pengaruh terhadap Kinerja manajerial SKPD. Partisipasi Anggaran, Kejelasan sasaran anggaran dan Struktur Desentralisasi memiliki pengaruh secara signifikan terhadap Kinerja manajerial SKPD di Pemerintah Kabupaten Lombok Barat.

Hal ini berarti bahwa partisipasi anggaran mendorong pelaksana anggaran mengenal dan menerima tujuan, serta bersungguh-sungguh mencapai tujuan yang telah ditetapkan melalui pencapaian efektifitas anggaran.Kejelasan sasaran anggaran dalam penyusunan anggaran merupakan hal mendasar yang perlu dimiliki oleh penyusun RKA agar anggaran dapat berfungsi secara efektif.Dengan adanya Struktur Desentralisasi di Pemerintah Kabupaten Lombok Barat menunjukkan bahwa tidak adanya pengaruh dalam pencapaian Kinerja manajerial SKPD.

Saran penelitian ini adalah sebaiknya pemerintah kabupaten lombok barat terus meningkatkan kejelasan sasaran anggaran terutama partisipasi anggaran dan struktur desentralisasi karena pemerintah daerah lombok barat kaitanya dengan partisipasi anggaran dan struktur desentralisasi tidak memberikan dampak terhadap kinerja manajerial. 
yang dapat mempengaruhi Kinerja manajerial SKPD, misalnya budget emphapasis, budgetary slack, umpan balik anggaran, komitmen organisasi, budaya organisasi dan variabel lainnya yang merupakan akuntansi keprilakuan. Penelitian selanjutnya sebaiknya dapat mengembangkan variabel lain misalnya dengan menambahkan variabel intervening atau moderasi. (Anthony, R., 1999)

\section{REFRENSI}

Anthony, R., N. A. V. G. (1999). Managemen Control System (Seventh Ed; Chicago : Richard D. Irwin, ed.)

Aprila, N dan Selvi Hidayani. (2012). The Effect Budgetary Participation, Asymmetry Information, Budget Emphasis and Comitment Organization to Budgetray Slack at SKPD Governmental of Bengkulu City. Procedding the 13 th. MICEMA.

Badan Pemeriksa Keuangan Republik Indonesia.(2014). Ikhtisar Hasil Pemeriksaan Anggaran semester II tahun 2014.

Brownwll, P, 1982, "Participation in the budgeting proses when it eork and when it doesn' $\mathrm{t}^{\prime \prime}$, journal of accounting leterature, Vol 1

Chong, V. K., \& Chong, K. M. (2002). Budget Goal Commitment and Informational Effects of Budget Participation on Performance: A Structural Equation Modeling Approach. Behavioral Research in Accounting. https://doi.org/10.2308/bria.2002.14.1.65

Dwiansari, R, (2004), Pengaruh hubungan antara struktur Desentralisasi dan partisipasi Penyusunan anggaran terhadap kinerja Dinas dengan komitmen organisasi sebagai variable intervening, Tesis, Program Pasca Sarjana UGM, Yogyakarta.

Fibrianti, D dan Riharjo, Ikhsan Budi. 2013. Pengaruh Partisipasi Anggaran, Desentralisasi, Komitmen Organisasi, dan Ketidakpastian Lingkungan Terhadap Kinerja Manajerial Pada Pemerintah Kota Surabaya. Jurnal Ilmu dan Riset Akuntansi Volume 1 Nomor 1.

Govindarajan, V, (1986), "Impact of Participation in the budgetary process on manegerial attitude and performance universalistic and cantingency perspective", Decisious Science.

Kurnia, P., Nasir, A., \& -, E. (2015). Pengaruh Akuntabilitas Publik, Partisipasi Penyusunan Anggaran, Kejelasan Sasaran Anggaran dan Struktur Desentralisasi terhadap Kinerja Aparat Pemerintah Daerah Skpd dengan Pengawasan Internal sebagai Variabel Pemoderasi Kab. Kuantan Singingi. Jurnal Online Mahasiswa Fakultas Ekonomi Universitas Riau.

Kusumaningrum, Indraswari. (2010). Pengaruh Kejelasan Sasaran Anggaran, Pengendalian Akuntansi, dan Sistem Pelaporan Terhadap Akuntabilitas Kinerja Instansi Pemerintah Provinsi Jawa Tengah. Tesis. Program Studi Magister Akuntansi Program Pasca Sarjana Universitas Dipenogoro : Jawa Tengah.

Mega Cahyani, N., \& Utama, I. (2015). Pengaruh Kejelasan Sasaran Anggaran,Pengendalian Akuntansi Dan Sistem Pelaporan Pada Akuntabilitas Kinerja. E-Jurnal Akuntansi.

Primadana, gede herry merta, Yuniarta, gede adi, \& Adiputra, made pradana. (2014). pengaruh partisipasi dalam penyusunan anggaran, kejelasan sasaran 
dan struktur desentralisasi terhadap kinerja manajerial SKPD dengan pengawasan internal sebagai variabel pemoderasi (studi empiris pada pemerintah kabupaten badung).Jurnal Akuntansi Program S1.

Nengsy, H., Nelly Sari, R., \& Agusti, R. (2013). Pengaruh Partisipasi Penyusunan Anggaran Terhadap Kinerja Manajerial Dengan Job Relevant Information, Kepuasan Kerja Dan Motivasi Sebagai Variabel Intervening. Akuntansi Sorot Magister Akuntansi Pasca Sarjana Universitas Riau.

Safitri, N. (2006). Pengaruh Partisipasi Dalam Penyusunan Anggaran Terhadap Kepuasan Kerjadan Kinerja Karyawan:Job Relevant Information (JRI) Sebagai Variabel Antara (Studi Pada PT. Merapi Utama Pharma Cabang Yogyakarta). Tesis.

Sembiring, Abel, S.T. (2008). Pengaruh partisipasi anggaran dan kejelasan sasaran anggaran terhadap kinerja manajerial dengan motivasi sebagai variabel moderating pada kawasan industry Medan.Tesis.USU.

Soetrisno. (2010). Pengaruh partisipasi, motivasi dan pelimpahan wewenang dalam penyusunan anggaran terhadap kinerja manajer (studi empiris pada dinas daerah dan lembaga teknis daerah di kabupaten Rembang). Tesis. Universitas Diponogoro

Sugiyono. (2002). Metode Penelitian Kuantitatif, Kualitatif dan R\&D. Alfa Beta. Bandung.

Sukandarrumudi. (2006). Metodelogi Penelitian Petunjuk Praktis Untuk Peneliti Pemula. Gajah Mada University Press, Yogyakarta.

Sumarno, J. (2005). Pengaruh komitmen organisasi dan gaya kepemimpinan terhadap hubungan antara partisipasi anggaran dan kinerja manajerial (Studi empiris pada kantor cabang perbankan Indonesia di Jakarta). SNA VIII Solo, 15-16 September. 